\title{
Molecular detection and quantification of the protozoan Bonamia ostreae in the flat oyster, Ostrea edulis
}

\author{
Maeva Robert ${ }^{a}$, Céline Garcia ${ }^{a},{\text { Bruno } \text { Chollet }^{a} \text {, Inmaculada Lopez-Flores }}^{b}$, Sylvie Ferrand ${ }^{a}$, \\ Cyrille François ${ }^{a}$, Jean-Pierre Joly ${ }^{a}$ and Isabelle Arzul ${ }^{a}{ }^{*}$
}

\author{
a Institut Français de Recherche pour l'Exploitation de la Mer (IFREMER), Laboratoire de Génétique et \\ Pathologie, av de Mus de Loup, 17390 La Tremblade, France \\ ${ }^{b}$ CIBEResp, Andalusian School of Public Health, c/ Cuesta del Observatorio, 4, 18080 Granada, Spain
}

*: Corresponding author : I. Arzul, Tel.: +33 5467626 10; fax: +33 5467626 11; email address : isabelle.arzul@ifremer.fr

\begin{abstract}
:
Bonamia ostreae is an intracellular protozoan which is recognized as a cause of mortality in European populations of flat oysters (Ostrea edulis). Based on the recent characterization of actin genes of $B$. ostreae, specific primers were designed for real-time PCR using SYBR ${ }^{\circledR}$ Green chemistry. Specificity was demonstrated by the unique melting temperature peak observed in positive samples and by the lack of amplification in samples of oysters infected by closely related parasites, including Bonamia exitiosa. A calibration curve using a cloned template was defined to estimate copy number. The assay had a 6 log- dynamic range, mean inter- and intra-assay variation coefficients of $<1 \%$ and a minimum detection limit of 50 gene copies per reaction. Using infected oyster samples as templates, the assay was at least 10 -fold more sensitive than conventional PCR. The quantitative assay was applied to test 132 oysters, and results were compared with the heart imprint method. There was a strong correlation between both techniques, and the results showed that the real-time PCR assay should be useful for studies of the ecology of $B$. ostreae and its host-parasite relationship.
\end{abstract}

Keywords: Bonamia ostreae; Real-time PCR; Detection; Quantification; Ostrea edulis; Heart imprints 


\section{Introduction}

Bonamia ostreae is an intracellular parasite of the flat oyster (Ostrea edulis), has a severe pathogenic effect on its host and causes major economic losses. This parasite is reported in Europe and North America [1, 2, 3, 4, 5, 6, 7, 8]. The closely related parasite, Bonamia exitiosa, was considered exotic to Europe and was only reported in the New Zealand dredge oyster (Ostrea chilensis) [9] and in the Australian mud oyster (O. angasi) [10,11, 12] until its detection in Spain in the European flat oyster (O. edulis) in 2007 [13]. B. exitiosa was reported in $O$. edulis, sometimes in association with $B$. ostreae inside the same individuals without increased mortality. $B$. ostreae and $B$. exitiosa appear to be very similar in morphology using traditional diagnostic tools (including histology or tissue imprints) used for disease surveillance [13]). Molecular tools presently available, such those based on PCR and in situ hybridization [14, 15, 16], target the 18S ribosomal RNA gene which is conserved among species of Bonamia [17]. These detection tools do not allow the delineation of Bonamia species, such that DNA sequencing needs to be used for species identification and differentiation. In an epidemiological context, tools enabling specific and rapid diagnosis of $B$. ostreae are required.

A lag time of three to five months is usually reported before the parasite is detected in oysters in an area affected by Bonamia [18, 19, 20]. However this inability to detect the parasites is probably due to a lack of sensitivity of diagnostic tests used. The use of molecular tools, such as PCR, is proposed to increase the sensitivity of the diagnostic approach, as suggested previously by Lynch et al. [21]. Prespawing oysters can die from bonamiosis [22], but individuals of $>2$ years of age appear to be more susceptible to the disease [18, 23, 24, 25], and death usually occurs concurrently with the highest intensity of infection $[26,27]$. Therefore, quantitative data on parasite burdens will be valuable for disease investigations and stock management.

Bonamiosis due to $B$. ostreae has an annual pattern that seems to differ according to the study site and climate or season. Two year-old oysters placed in Galicia showed maximum infection levels in August and September [28]. Maximum prevalence and infection levels in oysters sampled over a two years period in Ireland were recorded in spring and winter [25]. In The Netherlands, the peak of infection seems to occur in November-December [3, 19]. In France, prevalence also undergoes some fluctuation within a year, and is usually lowest in summer and highest in winter (Arzul, unpublished data).

This information raises issues regarding the sensitivity of diagnostic tests used in these studies and their suitability in studies aiming to estimate the prevalence and intensities of infection during an outbreak. Clearly, a robust, sensitive and quantitative assay is required to determine prevalence and intensity of infection. In the past, a semi quantitative assay based on examination of tissue imprints using oil immersion (x1000) under a light microscope has been used to estimate infection intensity [29]. Nevertheless, this technique is only semi-quantitative and skilled technicians are required to carry out the assay. Some real-time PCR assays targeting the 18S rDNA gene have been established for the detection of Bonamia species [8, 12], but were not quantitative

In this context, the objective of the present work was to develop a rapid and accurate technique allowing specific detection and quantification of $B$. ostreae in oysters. We developed a real-time PCR using primers targeting one of the actin genes characterized recently for $B$. ostreae [30], and we compared results with those achieved using heart imprint (HI) testing as well as conventional PCR [15]. 


\section{Material and Methods}

\subsection{Oysters}

Gill samples from flat oysters (O. edulis) were collected from various locations in France: Quiberon bay (South Brittany), Cancale (North Brittany), Granville oyster bed (Normandy) and La Tremblade (Charente Maritime). Samples of $5 \mathrm{~mm}$ were fixed in $90 \%$ ethanol. Gill pieces from oysters infected by parasites closely related to $B$. ostreae were also used to test the specificity of the primers and the PCR. These samples represented different oyster species which had been confirmed to be infected by $B$. exitiosa or related parasites; three $O$. chilensis originated from New Zealand, four $O$. chilensis from Chile, two O. puelchana from Argentina, one $O$. angasi from Australia, 27 O. edulis from Galician Rias, Mediterranean Sea and Adriatic sea. One O. edulis originating from The Netherlands, known to be infected with Haplosporidium armoricanum, and two Crassostrea gigas from Canada, known to be infected with Mikrocytos mackini, were also included the panel of control samples used to test the specificity of the assay.

\subsection{Heart imprint testing, and semi-quantification}

A heart imprint was performed on oyster that consisted of dissecting out the ventricle, drying it on paper and then performing several imprints on a slide. After air-drying for 5 min, imprints were fixed in absolute ethanol and then stained with Hemacolor ${ }^{\circledR}$ kit (Merck). Slides were observed under a light microscope (Olympus $\mathrm{BH}$ 51). The numbers of parasites were estimated on 3 to 5 microscopic fields of view (immersion oil X 100 objective, field diameter $220 \mu \mathrm{m}$, area $0.038 \mathrm{~mm}^{2}$ ) for each individual and the level of infection was determined by calculating the mean of these 3 to 5 examinations. The level of infection by the parasite classified as follows: negative results (0), when no parasite was detected, light infections $(1+)$, when a mean of 10 or fewer parasites was detected per microscopic field of view moderate infections (2+), when a mean between 10 and 50 parasites was obtained per field, heavy infections $(3+)$, when a mean of more than 50 parasites was obtained in each field.

\subsection{DNA extraction}

Gill tissue (25 mg) was collected from each oyster for DNA extraction using a QiaAmp DNA Minikit (Qiagen) according to the manufacturer's instructions. DNA was eluted and resuspended in

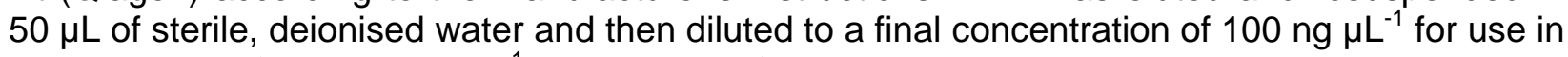
conventional PCR and $5 \mathrm{ng} \mathrm{LL}^{-1}$ in real-time PCR.

\subsection{Conventional PCR conditions and parasite species confirmation by PCR-RFLP}

Conventional PCR was performed according to Cochennec et al. [15]. The species of parasite was determined by digesting PCR products by Bg/l and Haell for $1 \mathrm{~h}$ [31, 32]. The efficiency of this method (PCR-RFLP) was tested independently by sequencing 57 PCR products, revealing same digestion profiles as those of $B$. ostreae. PCR products were sequenced bidirectionally using the Big Dye V3 sequencing kit (Applied Biosystem, U.S.A.) and plasmidic primers (TopoF: 5'-GAC CAT GAT TAC GCC AAG C 3' and TopoR: 5'CCC AGT CAC GAC GTT G-3'). Sequences obtained were compared with those available in the GenBank database using BLAST algorithm [33]. Comparisons showed that the sequences of all of these PCR products corresponded to those representing B. ostreae (AF192759, AF262995, AF162087) 


\subsection{Design of primers specific for actin 1 gene of $B$. ostreae}

Primers for the real-time PCR were designed based on the actin 1 gene sequences (GenBank accession nos. AM410919, AM410920 and AM410921) determined by Lopez-Flores et al. [30]. The primers were: forward-Bo A1F (5'-GCT TCG ACC GAA AGT TCC G-3') and reverse-Bo A2R (5'-GGCGAAGAGGTCTTTTCTGA-3'). These primers amplified a 201 bp product in PCR.

\subsection{Preparation of constructs as standards}

For the quantification of the intensity of $B$. ostreae infection in oysters, the actin 1 gene was amplified by PCR, cloned and used as standard control to generate a standard curve. Briefly, PCR products were obtained by amplifying a fragment of the actin 1 gene using primers Bo A1F and Bo A2R from the total genomic DNA extracted from highly infected oyster. PCR products were then cloned using the TOPO TA cloning kit (Invitrogen), according to manufacturer's recommendations; positive clones were then selected for plasmid DNA purification by QIAFilter ${ }^{\circledR}$ Plasmid Midi Kit (Qiagen).

Plasmid DNA was linearized prior to being diluted for PCR for the determination of the standard curve. Linearization was performed by digesting plasmid DNA using Xho I for $1 \mathrm{~h}$ at $37^{\circ} \mathrm{C}$. The enzyme was then inactivated by incubation for $15 \mathrm{~min}$ at $65^{\circ} \mathrm{C}$. DNA concentration was determined using a spectrophotometer, and gene copy number was estimated using serial dilutions of cloned DNA; DNA concentration in $\mathrm{g} \mathrm{L}^{-1} \times 610^{23}$ copies $\mathrm{mol}^{-1} /$ molecular weight of transformed plasmid in $\mathrm{g} \mathrm{mol}^{-1}$.

Plasmid DNA suspensions were then 10 -fold serial diluted from $4 \times 10^{6}$ copies $\mu \mathrm{L}^{-1}$ to 40 copies $\mu \mathrm{L}^{-1}$. Two additional dilutions were used for actin gene copy estimation: 20 and 10 copies $\mu \mathrm{L}^{-1}$. The PCR efficiency and correlation coefficient were estimated using the standard curve.

To examine the possibility that non target DNA would interfere with the assay, additional standard curves were developed by spiking $25 \mathrm{ng}$ of DNA from non infected control flat oyster with a serial dilution of plasmid DNA. Moreover, to ensure that intact $B$. ostreae DNA behaved the same as plasmid DNA, additional standard curves were established for the PCR using genomic DNA extracted from gills of a known infected flat oyster and 10-fold serial diluted from 5

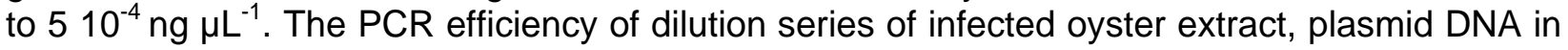
presence of oyster DNA was compared with that of plasmid DNA alone.

\subsection{Real-time PCR conditions and quantification}

Quantitative PCR was performed using a Mx3000 Thermocycler sequence detector (Stratagene). All reactions were carried out in 96-well plates in duplicate or triplicate in $25 \mu \mathrm{L}$ comprising $5 \mu \mathrm{L}$ of genomic DNA (sample) or plasmid DNA (positive control), $12.5 \mu \mathrm{L}$ of Brilliant $^{\circledR}$ SYBR $^{\circledR}$ Green I PCR Master Mix (Stratagene), $2.5 \mu \mathrm{L}$ of forward primer $(2.4 \mu \mathrm{M}), 2.5$ $\mu \mathrm{L}$ of reverse primer $(1.2 \mu \mathrm{M}), 0.375 \mu \mathrm{L}$ of Reference Dye $(1 \mathrm{mM})$ and $2.125 \mu \mathrm{L}$ of distilled water. Each PCR run included negative controls consisting in reaction mixtures without DNA and specimens that were known to contain no Bonamia ostreae DNA.

The following cycling conditions were used: $95^{\circ} \mathrm{C}$ for $10 \mathrm{~min}, 40$ cycles of amplification at $95^{\circ} \mathrm{C}$ for $30 \mathrm{~s}, 60^{\circ} \mathrm{C}$ for $1 \mathrm{~min}, 72^{\circ} \mathrm{C}$ for $30 \mathrm{~s}$. The fluorescence signal was collected at the end of each annealing step $\left(60^{\circ} \mathrm{C}\right)$. A post PCR melt curve was run according to the Mx3000 Thermocycler sequence detector User's Manual: a $30 \mathrm{~s}$ hold at $95^{\circ} \mathrm{C}$, a $30 \mathrm{~s}$ hold at $60^{\circ} \mathrm{C}$, and a 40 min slow ramp from 60 to $95^{\circ} \mathrm{C}$. .

Threshold cycles $\left(C_{t}\right)$, defined as the cycle at which a statistically significant increase in fluorescence output above background is detected, were calculated automatically by the Stratagene thermocycler software. $C_{t}$ values were calculated as averages of the three replicates or duplicates within each reaction. Quantitative standards (serial dilution of plasmid DNA) and no template controls (NTC = deionised, sterile water) controls were included in each PCR run. The 
estimation of the actin gene copy number for $B$. ostreae was carried out by comparing $C_{t}$ values obtained for each sample with the standard curve.

\subsection{Specificity of real-time PCR assay}

The specificity of the amplified products was confirmed by a melting curve analysis. In addition, oysters detected positive by real-time PCR were tested by PCR-RFLP and sequencing in order to confirm the parasite species. DNA extracted from different species of oysters infected by parasites other than $B$. ostreae was subjected to real-time PCR to test specificity.

\subsection{Sensitivity}

The sensitivity of the SYBR ${ }^{\circledR}$ Green - based real-time PCR assay was measured using serially diluted plasmid DNA containing the actin 1 gene. The range consisted of 10 -fold dilutions

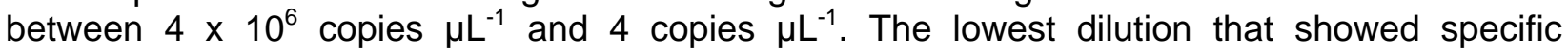
amplification was further diluted (two-fold) serially. Genomic DNA extracted from two highly infected oysters was also diluted (10-fold) serially and subject to conventional PCR according to Cochennec et al. [15] as well as real-time PCR using the present real-time PCR assay. The lowest dilution that showed specific amplification was further diluted (two-fold) serially and tested by both assays.

\subsection{Assay precision}

Triplicate $C_{t}$ values obtained from a dilution series (from $4 \times 10^{7}$ to $4 \times 10^{2}$ copies $\mu L^{-1}$ ) of plasmid preparation were used to measure intra assay coefficient of variation. Three separate dilution series (from $4 \times 10^{7}$ to 40 copies $\mu^{-1}$ ) of plasmid were tested independently on three different days. The mean, standard deviation and variation coefficient were calculated separately for each plasmid dilution in order to evaluate inter-assay variation.

\subsection{Statistical analyses}

The $C_{t}$ values, the deduced numbers of actin gene copies $\mu g^{-1}$ of total DNA and the estimated numbers of parasites per tissue imprint were $\log (x+1)$-transformed prior to statistical analyses, in order to improve the normality of the data and the homogeneity of variance [34]. Pearson's correlation coefficients between real-time PCR and heart imprint results were determined using the procedure PROC CORR from the SAS software package, and a linear regression was performed between the log-value of numbers of parasites per tissue imprint and the log-value of actin gene copies $\mu^{-1}$ of total DNA (estimated by real-time PCR) using the procedure PROC REG [35]. 


\section{Results}

\subsection{Standard curve and dynamic range}

Linear relationship between plasmid DNA copies and $C_{t}$ values was observed for over $6 \log _{10}$ dilutions (from 40 to $4 \times 10^{6}$ copies $\mu \mathrm{L}^{-1}$ ) with a regression coefficient $(r)$ of 0.99 , a slope of 3.345 ( \pm 0.0222$)$ suggesting an optimum PCR efficiency $\left(\left[10^{(-1 / \text { slope })}-1\right]\right)$ of $101.3 \% \pm 2.53$ (Table 2). The PCR efficiencies for plasmid DNA spiked with $25 \mathrm{ng}$ not infected oyster DNA per reaction and for infected oyster DNA were similar to PCR efficiency obtained for plasmid DNA alone. In the presence of oyster DNA, the plasmid showed a correlation coefficient of 0.999 and PCR efficiency of $97.4 \%$. The PCR efficiency for DNA extracted from $B$. ostreae infected oyster was $102.2 \%$ with a correlation coefficient of 0.998 .

\subsection{Specificity of real-time PCR assay}

A unique melting peak at $81.7^{\circ} \mathrm{C} \pm 0.21$ was observed after the real-time PCR with DNA extracted from oysters confirmed to be infected by parasites belonging to the genus Bonamia by heart imprints (Fig. 1). Eight of these samples were tested by PCR-RFLP and sequenced in order to confirm that these oysters were infected by $B$. ostreae. PCR products from two of the samples were also cloned and then 19 and 10 clones were subsequently tested by PCR-RFLP. All restriction profiles and sequences were the same as B. ostreae ones (AF192759, AF262995, AF162087).

The assay was applied to DNA extracted from 37 individual oysters infected by $B$. exitiosa or closely related parasites, one oyster known to be infected by $H$. armoricanum and two oysters infected by $M$. mackini. No amplification was detected for any of these samples. As expected, the NTC did not yield an amplicon.

\subsection{Sensitivity of real-time PCR and comparison with conventional PCR}

The sensitivity of the assay was evaluated by using serial dilutions of plasmid DNA (from $4 \times 10^{6}$ copies $\mu \mathrm{L}^{-1}$ to 4 copies $\mu_{\mathrm{L}}^{-1}$ ). The real-time PCR was able to achieve amplification from as few as 10 copies $\mu \mathrm{L}^{-1}$ (50 plasmid copies per reaction).

Two serial dilutions prepared from DNA extracted from highly infected oysters were tested twice by the real-time PCR assay and by conventional PCR. Quantification of $B$. ostreae actin gene

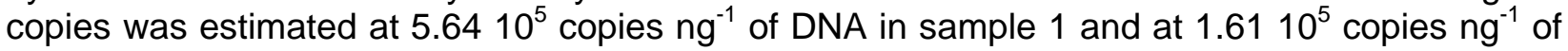
DNA in sample 2 by our quantitative assay

The last dilution which allowed repeated detection of $B$. ostreae by real-time PCR was $5 \times 10^{-4}$ $\mathrm{ng} \mu \mathrm{L}^{-1}$ (corresponding to $1.41 \times 10^{3}$ parasite actin gene copies per reaction) for the first sample

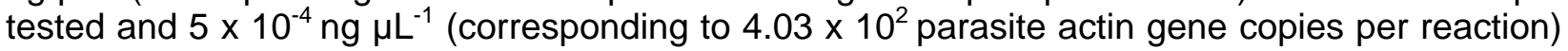
for the second sample tested. For the same amounts of DNA, conventional PCR showed repeated positive signal until dilution $5 \times 10^{-1} \mathrm{ng}^{-1} \mathrm{~L}^{-1}$ (estimated to correspond to $1.41 \times 10^{6}$ parasite actin gene copies per reaction by real-time PCR) for sample 1 and $5 \times 10^{-3} \mathrm{ng}^{-1}$ (estimated to correspond to $4.03 \times 10^{3}$ parasite actin gene copies per reaction by real-time PCR) for sample 2. 


\subsection{Assay Precision}

The PCR assays performed on triplicate from a same plasmid DNA dilution on the same plate and on three independent plasmid DNA dilution series on different days demonstrated low variability (Tables 1 and 2). The mean intra-assay coefficient of variation calculated from triplicate $\mathrm{C}_{\mathrm{t}}$ values was $0.69 \% \pm 0.29$. The coefficient of variation of replicate tests on different days was $0.71 \% \pm 0.48 \%$.

\subsection{Testing of samples from oysters}

Samples $(n=132)$ were tested conventionally via heart imprints and conventional PCR as well as real-time PCR. Heart imprints allowed categorizing samples according to their level of infection by $B$. ostreae; 43 samples were test negative using this approach; 24 samples had a light infection (with a mean of 1 to 6 parasites per microscopic field of view per oyster); 17 exhibited moderate infection level (with a mean of 10.4 to 44 parasites per microscopic field of view per oyster); 48 oysters had a high intensity of infection (with a mean of 54.6 to 309 parasites per microscopic field of view). Details of examination of heart imprints for oysters found infected are given in Tables 3 to 5 .

Conventional PCR gave results that were very similar to those achieved using the heart imprint examination: all the oysters found to be test negative in the cytological technique were also test negative using the PCR. All oysters found infected, except one individual lightly infected by heart imprint, appeared positive by PCR.

The $C_{t}$ values of real-time PCR demonstrated differences in the amount of parasite actin gene copies between oysters found not infected, lightly, moderately and highly infected (Fig. 2).

Real-time PCR assay conducted on oysters that were test negative by heart imprints and by conventional PCR did not yield any specific amplification for 24 samples. A specific amplification, as confirmed by the melting curve analysis, was obtained for both duplicates of 10 samples and for one of the duplicates of 9 samples. $C_{t}$ values obtained for these 19 samples considered positive by our assay were above 34.2 and presented a median of 36.49 . These Ct values were outside the range of our standard curve and thus did not allow us to estimate parasite actin gene copies.

Real-time PCR performed on the three groups of oysters that were test positive by heart imprint

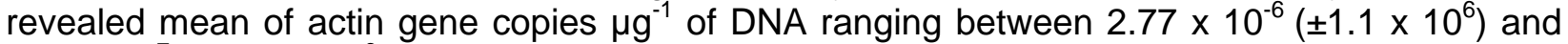
$1.02 \times 10^{7}\left( \pm 5.53 \times 10^{6}\right)$ with corresponding Ct values of 29.86 and 23.34 respectively (Tables 3 , 4 and 5).

The number of $B$. ostreae actin gene copies per oyster cell was deduced from the mean of DNA content of $O$. edulis genome estimated at $2.33 \mathrm{pg}$ [36] and making the assumption that cells in tested samples corresponded to diploid, non-dividing cells. Oysters detected lightly, moderately and highly infected by heart imprints related to a mean of $6.44,12$ and 23.34 parasite actin gene copies per cell respectively.

Comparison of results obtained by real-time PCR and by heart imprint yielded a Pearson's correlation coefficient of -0.90 between log (1+ number of parasites estimated by heart imprint) and $\log \left(1+C_{t}\right.$ value $)(p<0.0001)$ and 0.82 between log $(1+$ number of parasites estimated by heart imprint) and log (1+ deduced numbers of actin gene copies $\mu g^{-1}$ of total DNA) $(p<0.0001)$ (Fig. 3). 


\section{Discussion}

Bonamiosis due to $B$. ostreae is a systemic disease that causes mortality in affected stocks of $O$. edulis. Host mortality is correlated with a high intensity of infection, which can be estimated by tissue imprints according to the scale proposed by Hervio et al. [29]. However, this technique is not specific, is semi-quantitative and categorises oysters in four groups: not infected, lightly infected, moderately infected and highly infected. Here, we have developed a rapid, specific and sensitive real-time PCR assay allowing detection and quantification of $B$. ostreae DNA in oyster samples.

The diagnosis of mollusc diseases usually relies on histology and cytology (including tissue imprints). However, these techniques do not usually achieve specific identification or delineation, and molecular tools are generally required for species confirmation. Nevertheless, some tools available for the diagnosis of bonamiosis are not specific and produce an amplification product for all members of the genus Bonamia and closely related parasites within the Order Haplosporidia, such as Haplosporidium nelsoni [17]. In this case, confirmation of the parasite species is determined by sequencing the amplicon. In the past, geographical distribution and host specificity of some members of the genus Bonamia was distinct, with $B$. ostreae being reported in $O$. edulis in Europe and North America and $B$. exitiosa being described in $O$. chilensis in New Zealand and $O$. angasi in Australia. Based on this information, a consistent in morphology to Bonamia in flat oysters in Europe was considered to be $B$. ostreae but the specific identity had not been verified by molecular analysis.

The distribution and host specificity have been updated regularly, with detection of new Bonamia isolates in new host species in new parts of the world. More specifically, in October 2007, $B$. exitiosa was reported for the first time in flat oysters $O$. edulis from Galicia, Spain [13]. In this context, the development of specific tools for the rapid detection and discrimination of Bonamia parasites was required. Based on the recent characterization of actin genes of $B$. ostreae [30], we designed primers for a real-time PCR assay. Eight samples yielding amplification by this assay with an expected melting peak of $81.7^{\circ} \mathrm{C} \pm 0.21$ were tested by PCR-RFLP which confirmed that these oysters were infected by $B$. ostreae. Additionally, two samples were cloned, and 19 and 10 clones were tested by PCR-RFLP. The digestion profile for all samples was of the same as $B$. ostreae one suggesting that these two oysters were not co infected by other Bonamia species. The real-time PCR assay established was then applied to genomic DNA extracted from oysters infected by different members of the genus Bonamia as well as from oysters infected by $\mathrm{H}$. armoricanum and M. mackini. The lack of amplification in all these samples shows a strong analytical specificity of the technique.

Quantification was achieved using a standard curve constructed by amplifying known amounts of target DNA in parallel set of reactions (ABI 2006). When a target DNA originates from an uncultivated micro-organism, plasmid DNA standards are often used. Such approach was already developed for detection and quantification of pathogens including protistans like Plasmodium falciparum [37], Alexandrium minutum [38] or Babesia gibsoni [39]. B. ostreae cannot be cultured in vitro; the development of standard curve using plasmid DNA containing the targeted parasite DNA region Bo A1F Bo A2R has allowed quantification of actin genes in tested samples over a 6 log range with an efficiency of 101.3\%. Addition of non-target DNA as well as testing DNA extracted from infected oysters did not impair the efficiency of the reaction; 50 plasmid copies per reaction could be successfully detected by our real-time assay and was considered as the detection limit for this method. However, it is recognised that plasmid DNA is more easily amplified than mix of target and non-target DNA [38, 40]. Dilutions prepared from highly infected individuals were tested by real-time and conventional PCR according to Cochennec et al. [15] in order to compare detection limit of both assays. Although the 18S rDNA gene, targeted by the conventional PCR assay might be present in multiple copies in the 
parasite genome, real-time PCR appears to be at least ten-times more sensitive than conventional PCR, depending samples tested.

Tests conducted to evaluate intra- and inter-assay variability revealed very low values $(<1 \%$, Tables 1 and 2), and good repeatability and reproducibility of results.

In the present study, we recorded results in copy numbers per $\mu g$ of total DNA template. Recording results as copy numbers $\mathrm{mg}^{-1}$ of tissue might be problematic because of differences in DNA extraction efficiency, in effects of sample size and sample quality. However, number of $B$. ostreae actin gene copies per oyster cell was estimated by taking into account results of Rodriguez -Juiz et al. [36] and by making the assumption that all cells in the samples tested were diploid and not undergoing division.

The application of our assay to 132 oysters examined by heart imprints and categorised in 4 groups (not infected; lightly infected; moderately infected and highly infected) after observation of five microscopic fields of view per oyster served to validate the assay. All oysters detected shown by heart imprint or PCR to be test positive were also positive using the quantitative PCR assay. Besides, 19 oysters found not to be infected by heart imprint and conventional PCR yielded specific amplification using real-time PCR. $C_{t}$ values obtained for these 19 samples were outside of the range of the standard curve and thus did not allow an estimation of actin gene copy number. These results suggest that samples shown to be test negative by heart imprint and conventional PCR could be lightly infected by $B$. ostreae and thus could be test positive $y$ real-time PCR. The lack of sensitivity of the heart imprint approach is recognised as a limitation of assay, and molecular tools should have increased sensitivity. However, this is not always the case [41]. Moreover, molecular tools detect parasite DNA and do not confirm presence of viable pathogens and established infection. Interpretation of results for samples that are negative by heart imprints and positive by real-time PCR is thus difficult and open to debate.

Comparison of the results obtained by heart imprints and real-time PCR showed a very good correlation $(0.82, p<0.0001)$ between both techniques. Oysters shown to be lightly infected by heart imprint showed a mean of actin gene copies $\mu g^{-1}$ of total DNA of $2.77 \times 10^{6}$ or 6.44 actin gene copies per host cell. These results suggest that oysters with light infections by heart imprint already have advanced disease. Moreover, the lack of correlation between PCR and imprint observed in some studies most probably relates to an inability of the heart imprint method to detect low level primary primary infections.

In conclusion, a SYBR ${ }^{\circledR}$ Green-Based real-time PCR assay was established for monitoring and quantification of $B$. ostreae in the gill tissue of oysters. This assay was shown to be sensitive and specific and, moreover, was able to generate reproducible results. Comparison showed a very good correlation between heart imprint and the real-time PCR techniques. Thus this assay may be used in the future for detection and monitoring bonamiosis in various tissues of infected oyster and may be adapted for parasite detection in the environment to improve the knowledge of the parasite life cycle within and outside of the host.

\section{Acknowledgements}

Authors thank D. Stone for his valuable critical comments on the manuscript and for revising the English text. This work was supported by EU DG Sanco through the Community Reference Laboratory for Mollusc Diseases, Ifremer, La Tremblade. The authors thank Dr. J. Campalans for providing Ostrea chilensis infected with Bonamia sp., Dr. M. Hine for providing O. chilensis infected with Bonamia exitiosa, Dr. M. Kroeck for providing O. puelchana infected with Bonamia sp., Dr. S. Corbeil for providing $O$. angasi infected with B. exitiosa, Dr. G. Tiscar and Dr. A. Villalba for providing $O$. edulis infected with $B$. exitiosa, Dr. M. Engelsma for providing O.edulis infected with Haplosporidium armoricanum and G. Meyer for providing Crassostrea gigas 
infected with Mikrocytos mackini.. A. Langlade, D. Gerla, M. Bouchoucha and E. Le Gagneur are also acknowledged for supplying flat oysters from Quiberon Bay, Cancale, Corsica and Granville, France.

\section{References}

[1] Pichot Y, Comps M, Tige G, Grizel H, Rabouin MA. Research on Bonamia ostreae gen. n., sp. n., a new parasite of the flat oyster Ostrea edulis L. Rev Trav ISTPM 1979;43:131-140.

[2] Bucke D, Hepper B, Key D, Bannister C.A. A report on Bonamia ostreae in Ostrea edulis in the UK. Cons. Inter. Explor. Mer, CM 1984/K 1984;9:1-7.

[3] Van Banning P. Control of Bonamia in Dutch oyster culture. In: Ellis AE, editor. Fish and Shellfish Pathology. Academic Press, London; 1985. p. 393-396.

[4] Elston RA, Farley CA, Kent ML. Occurrence and significance of bonamiasis in European flat oysters Ostrea edulis in North America. Dis Aquat Organ 1986;2:49-54.

[5] Friedman CS, McDowell T, Groff JM, Hollibaugh JT, Manzer D, Hedrick RP. Presence of Bonamia ostreae among populations of the European flat oyster, Ostrea edulis Linne, in California, USA. J Shellfish Res 1989;8:133-137.

[6] Figueras AJ. Bonamia status and its effects in cultured flat oysters in the Ria de Vigo, Galicia (N.W. Spain). Aquaculture 1991;93:225-233.

[7] McArdle JF, McKiernan F, Foley H, Jones DH. The current status of Bonamia disease in Ireland. Aquaculture 1991;93:273-278.

[8] Marty GD, Bower SM, Clarke KR, Meyer G, Lowe G, Osborn AL, Chow EP, Hannah H, Byrne $\mathrm{S}$, Sojonky K, Robinson JH. Histopathology and a real-time PCR assay for detection of Bonamia ostreae in Ostrea edulis cultured in western Canada. Aquaculture 2006;261:33-42.

[9] Dinamani P, Hine PM, Jones JB. Occurrence and characteristics of the haemocyte parasite Bonamia sp. in the New Zealand dredge oyster Tiostrea lutaria. Dis Aquat Organ 1987;3: 37-44.

[10] Hine PM, Jones JB. Bonamia and other aquatic parasites of importance to New Zealand. NZ J Zool 1994;21: 49-56.

[11] Hine PM. The ecology of Bonamia and decline of bivalve molluscs. NZ J Ecol 1996;20:109116.

[12] Corbeil S, Arzul I, Diggles B, Heasman M, Chollet B, Berthe FCJ, Crane MSJ. Development of a TaqMan PCR assay for the detection of Bonamia species. Dis Aquat Organ 2006;71:75-80.

[13] Abollo E, Ramilo A, Casas SM, Comesaña P, Cao A, Carballal MJ, Villalba A. First detection of the protozoan parasite Bonamia exitiosa (Haplosporidia) infecting flat oyster Ostrea edulis grown in European waters. Aquaculture 2008;274:201-207.

[14] Carnegie R, Barber BJ, Culloty SC, Figueras AJ, Distel DL. Development of a PCR assay for detection of the oyster pathogen Bonamia ostreae and support for its inclusion in the Haplosporidia. Dis Aquat Organ 2000;42:199-206.

[15] Cochennec N, Le Roux F, Berthe F, Gerard A. Detection of Bonamia ostreae based on small subunit ribosomal probe. J Invertebr Pathol 2000;76:26-32.

[16] Carnegie RB, Barber BJ, Distel DL. Detection of the oyster parasite Bonamia ostreae by fluorescent in situ hybridization. Dis Aquat Organ 2003;55:247-252.

[17] Carnegie RB, Cochennec-Laureau N. Microcell parasites of oysters: Recent insights and future trends. Aquat Liv Res 2004;17:519-528.

[18] Grizel H. Etudes des récentes épizooties de l'huître plate Ostrea edulis L. et de leur impact sur l'ostréiculture bretonne. Thèse de doctorat, Université des Sciences et Techniques de Languedoc, Montpellier, France; 1985. 
[19] Van Banning P. The life cycle of the oyster pathogen Bonamia ostreae with a presumptive phase in the ovarian tissue of the European flat oyster, Ostrea edulis. Aquaculture 1990;84:189192.

[20] Montes J. Lag time for the infestation of flat oyster (Ostrea edulis L.) by Bonamia ostreae in estuaries of Galicia (N.W. Spain). Aquaculture, 1991;93:235-239.

[21] Lynch SA, Armitage DV, Wylde S, Mulcahy MF, Culloty SC. The susceptibility of young prespawning oysters, Ostrea edulis, to Bonamia ostreae. J Shellfish Res 2005;24:1019-1025.

[22] Lallias D, Arzul I, Heurtebise S, Ferrand S, Chollet B, Robert M, Beaumont AR, Boudry P, Morga $B$, Lapègue $S$. Bonamia ostreae-induced mortalities in one-year old European flat oysters Ostrea edulis: experimental infection by cohabitation challenge. Aquat Living Resour 2008;21:423-439.

[23] Balouet G, Poder M, Cahour A. Haemocytic parasitosis : morphology and pathology of lesions in the French flat oyster, Ostrea edulis L. Aquaculture 1983;34:1-14.

[24] Robert R, Borel M, Pichot Y, Trut G. Growth and mortality of the European oyster Ostrea edulis in the Bay of Arcachon (France). Aquat Living Resour 1991;4:265-274.

[25] Culloty SC, Mulcahy MF. Season-, age-, and sex-related variation in the prevalence of bonamiosis in flat oysters (Ostrea edulis L.) on the South coast of Ireland. Aquaculture 1996;144:53-63.

[26] Brehelin M, Bonami JR, Cousserand F, Vivares CP. Existence de formes plasmodiales vraies chez Bonamia ostreae parasite de I'hu?re plate Ostrea edulis. L.C.R. Acad. Sc., Paris, S?. III 1982;295:45-48.

[27] Caceres-Martinez J, Robledo JAF, Figueras A. Presence of Bonamia and its relation to age, growth rates and gonadal development of the flat oyster, Ostrea edulis, in the Ria de Vigo, Galicia (NW Spain). Aquaculture 1995;130:15-23.

[28] Montes J, Melendez MI. Data on the parasitism of Bonamia ostreae in the flat oyster of Galicia, north-west coast of Spain. Aquaculture 1987;67:195-198.

[29] Hervio D, Bachere E, Boulo V, Cochennec N, Vuillemin V, Le Coguic Y, Cailletaux G, Mazurie J, Mialhe E. Establishment of an experimental infection protocol for the flat oyster Ostrea edulis with the intrahaemocytic protozoan parasite Bonamia ostreae: application in the selection of parasite-resistant oyster. Aquaculture 1995;132:183-194.

[30] López-Flores I, Súarez-Santiago VN, Longet D, Saulnier D, Chollet B, Arzul I. Characterization of actin genes in Bonamia ostreae and their application to phylogeny of the Haplosporidia, Parasitol 2007;134:1941-1948.

[31] Hine PM, Cochennec-Laureau N, Berthe FCJ. Bonamia exitiosus n. sp. (Haplosporidia) infecting flat oysters Ostrea chilensis (Philippi) in New Zealand. Dis Aquat Organ 2001;47:6372.

[32] Cochennec N, Reece KS, Berthe FCJ, Hine PM. Revisiting Mikrocytos roughleyi taxonomic affiliation points to the genus Bonamia (Haplosporidia). Dis Aquat Organ 2003;54:209-217.

[33] Altschul SF, Madden TL, Schaffer AA, Zhang J, Zhang Z, Miller W, Lipman DJ Gapped BLAST and PSI-BLAST: a new generation of protein data base search programs. Nucleic Acids Res 1997;25:3389-3402.

[34] Sokal RR, Rohlf FJ. Biometry: the principles and practice of statistics in biological research. Third edition. New York: Freeman; 1995.

[35] SAS Institute Inc. SAS Institute Inc. (Fourth edition), SAS/STAT® User's Guide, Version 6, SAS Institute Inc., Cary, NC 1990.

[36] Rodriguez -Juiz AM, Torrado M, Mendez J. Genome-size variation in bivalve molluscs determined by flow cytometry. Mar Biol 1996;126:489-497.

[37] Gama BE, Silva-Pires Fdo E, Lopes MN, Cardoso MA, Britto C, Torres KL, de Mendonça Lima L, de Souza JM, Daniel-Ribeiro CT, Ferreira-da-Cruz Mde F. Real-time PCR versus conventional PCR for malaria parasite detection in low-grade parasitemia. Exp Parasitol 2007;16:427-432. 
[38] Galluzzi L, Penna A, Bertozzini E, Vila M, Garcés E, Magnani M. Development of a real-time PCR assay for rapid detection and quantification of Alexandrium minutum (a Dinoflagellate).Appl Environ Microbiol 2004;70:1199-1206.

[39] Matsuu A, Ono S, Ikadai H, Uchide T, Imamura S, Onuma M, Okano S, Higuchi S. Development of a SYBR green real-time polymerase chain reaction assay for quantitative detection of Babesia gibsoni (Asian genotype) DNA. J Vet Diagn Invest 2005;17:569-73.

[40] Sivaganesan M, Seifring S, Varma M, Haugland RA, Shanks OC. A Bayesian method for calculating real-time quantitative PCR calibration curves using absolute plasmid DNA standards.BMC Bioinformatics 2008;9:120.

[41] Lynch SA, Mulcahy MF, Culloty SC. Efficiency of diagnostic techniques for the parasite, Bonamia ostreae, in the flat oyster, Ostrea edulis. Aquaculture 2008;281:17-21.

\section{Tables}

\begin{tabular}{|c|c|c|c|c|c|c|c|}
\hline \multirow[t]{2}{*}{ Copies } & \multicolumn{3}{|c|}{$C_{t}$ value } & \multirow[t]{2}{*}{ Mean value } & \multirow[t]{2}{*}{ S.D. } & \multirow[t]{2}{*}{$C V$} & \multirow{2}{*}{$\begin{array}{c}\text { Intra-assay } \\
\text { variability }\end{array}$} \\
\hline & $\mathrm{C} 1$ & $\mathrm{C} 2$ & C3 & & & & \\
\hline $1.95 e+008$ & 13.81 & 13.46 & 13.71 & 13.66 & 0.15 & $1.08 \%$ & Mean \\
\hline $1.95 \mathrm{e}+007$ & 16.90 & 16.65 & 16.77 & 16.77 & 0.10 & $0.61 \%$ & SD \\
\hline $1.95 e+006$ & 20.15 & 19.92 & 19.62 & 19.90 & 0.22 & $1.09 \%$ & \\
\hline $1.95 e+005$ & 23.72 & 23.48 & 23.64 & 23.61 & 0.10 & $0.42 \%$ & $0.69 \%$ \\
\hline $1.95 e+004$ & 26.91 & 26.71 & 26.61 & 26.74 & 0.12 & $0.47 \%$ & $0.29 \%$ \\
\hline $1.95 \mathrm{e}+003$ & 30.33 & 30.10 & 30.01 & 30.15 & 0.13 & $0.45 \%$ & \\
\hline
\end{tabular}

Table 1 - Intra-assay variability calculated from triplicate (C1, C2 and C3) of a same plasmid DNA dilution on the same plate. SD: Standard Deviation. CV: Coefficient of Variation 


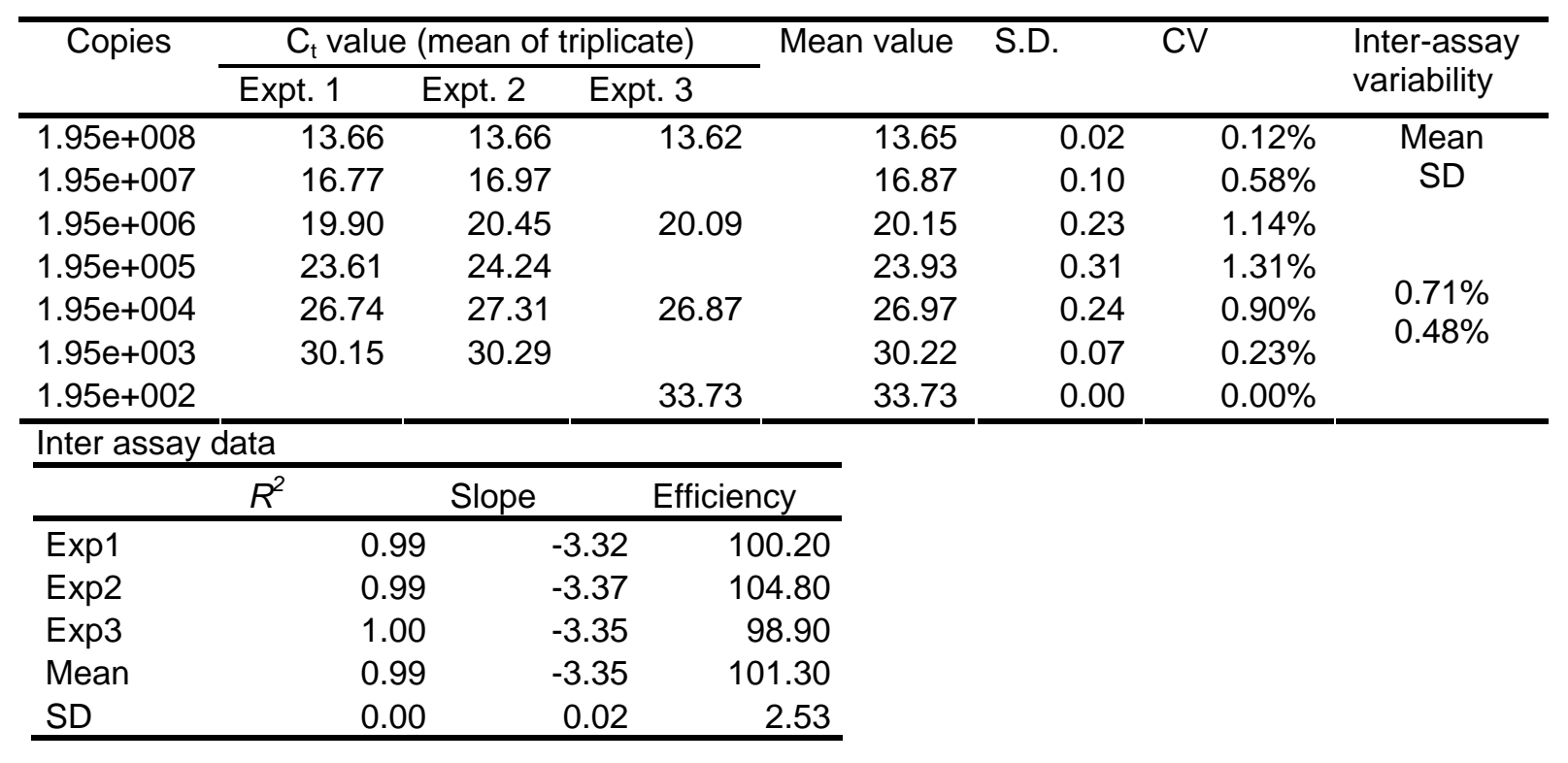

Table 2 - Inter-assay variability calculated from three independent plasmid DNA dilution series tested by real-time PCR on different days (Expt.1, Expt. 2 and Expt. 3). SD: Standard Deviation. $C V$ : Coefficient of Variation. $R$ : Correlation coefficient 


\begin{tabular}{|c|c|c|c|c|c|c|c|c|c|c|}
\hline & \multicolumn{6}{|c|}{$\begin{array}{c}\text { Number of parasites per microscopic field } \\
\text { of view }\end{array}$} & \multirow{2}{*}{$\begin{array}{c}\text { Conventional } \\
\text { PCR }\end{array}$} & \multirow{2}{*}{$\begin{array}{l}\text { Real-time } \\
\text { PCR } \\
\mathrm{C}_{\mathrm{t}} \text { value } \\
\text { (mean of } \\
\text { duplicates) }\end{array}$} & \multirow{2}{*}{$\begin{array}{l}\text { Calculated } \\
\text { number of } \\
\text { actin gene } \\
\text { copies } \mu g^{-} \\
{ }_{1} \text { of DNA }\end{array}$} & \multirow{2}{*}{$\begin{array}{l}\text { Estimated } \\
\text { number of } \\
\text { actin gene } \\
\text { copies per } \\
\text { oyster cell }\end{array}$} \\
\hline & 1 & 2 & 3 & 4 & 5 & mean & & & & \\
\hline 1 & 2 & 1 & 1 & 2 & 1 & 1.4 & + & 27.67 & $5.09 E+05$ & $1.18 \mathrm{E}+00$ \\
\hline 2 & 1 & 5 & 2 & 2 & 2 & 2.4 & + & 30.01 & 1.07E+05 & 2.49E-01 \\
\hline 3 & 1 & 8 & 3 & 1 & 2 & 3 & + & 29.47 & 1.53E+05 & 3.56E-01 \\
\hline 4 & 1 & 2 & 2 & 1 & 1 & 1.4 & + & 29.79 & $1.24 \mathrm{E}+05$ & 2.88E-01 \\
\hline 5 & 5 & 2 & 1 & 1 & 3 & 2.4 & + & 28.74 & $2.50 \mathrm{E}+05$ & 5.81E-01 \\
\hline 6 & 1 & 0 & 0 & 0 & 0 & 0.2 & + & 32.75 & $1.71 \mathrm{E}+04$ & 3.98E-02 \\
\hline 7 & 7 & 4 & 4 & 7 & 6 & 5.6 & + & 23.74 & 7.07E+06 & $1.64 \mathrm{E}+01$ \\
\hline 8 & 5 & 13 & 1 & 3 & 5 & 5.4 & + & 20.67 & $5.50 E+07$ & $1.28 \mathrm{E}+02$ \\
\hline 9 & 1 & 0 & 0 & 1 & 0 & 0.4 & + & 31.21 & $4.79 E+04$ & 1.11E-01 \\
\hline 10 & 1 & 2 & 1 & 1 & 2 & 1.4 & + & 31.76 & $3.31 E+04$ & 7.70E-02 \\
\hline 11 & 3 & 4 & 1 & 1 & 2 & 2.2 & + & 32.97 & 1.47E+04 & 3.43E-02 \\
\hline 12 & 1 & 1 & 4 & 1 & 1 & 1.6 & - & 33.73 & $8.90 \mathrm{E}+03$ & 2.07E-02 \\
\hline 13 & 1 & 0 & 0 & 0 & 0 & 0.2 & + & 29.30 & $1.72 \mathrm{E}+05$ & 3.99E-01 \\
\hline 14 & 4 & 1 & 2 & 1 & 1 & 1.8 & + & 35.45 & $2.82 \mathrm{E}+03$ & 6.56E-03 \\
\hline 15 & 2 & 0 & 0 & 0 & 0 & 0.4 & + & 27.55 & $5.53 E+05$ & $1.29 E+00$ \\
\hline 16 & 8 & 1 & 1 & 1 & 1 & 2.4 & + & 30.60 & $7.20 \mathrm{E}+04$ & 1.68E-01 \\
\hline 17 & 5 & 2 & 3 & 2 & 2 & 2.8 & + & 28.65 & $2.65 E+05$ & 6.17E-01 \\
\hline 18 & 1 & 4 & 1 & 1 & 1 & 1.6 & + & 32.43 & $2.08 E+04$ & $4.85 \mathrm{E}-02$ \\
\hline 19 & 1 & 2 & 1 & 1 & 1 & 1.2 & + & 30.47 & $7.81 E+04$ & $1.82 \mathrm{E}-01$ \\
\hline 20 & 1 & 1 & 1 & 1 & 1 & 1 & + & 32.49 & $2.00 E+04$ & 4.65E-02 \\
\hline 21 & 1 & 1 & 2 & 1 & 1 & 1.2 & + & 31.42 & $4.12 \mathrm{E}+04$ & 9.58E-02 \\
\hline 22 & 2 & 4 & 1 & 2 & 2 & 2.2 & + & 30.22 & $9.22 \mathrm{E}+04$ & $2.14 \mathrm{E}-01$ \\
\hline 23 & 3 & 2 & 1 & 2 & 1 & 1.8 & + & 29.65 & $1.35 E+05$ & 3.14E-01 \\
\hline 24 & 5 & 3 & 5 & 4 & 6 & 4.6 & + & 25.93 & $1.65 E+06$ & $3.83 E+00$ \\
\hline Mean & & & & & & 2.025 & & 29.86 & $2.77 \mathrm{E}+06$ & $6.44 \mathrm{E}+00$ \\
\hline
\end{tabular}

Table 3 - Comparison of results obtained by heart imprints (based on examination of 3 to 5 microscopic fields of view), conventional PCR and real-time PCR for flat oysters detected lightly infected by heart imprints. The estimated number of actin gene copies per oyster cell is deduced from the mean of DNA content of Ostrea edulis genome estimated at $2.33 \mathrm{pg}$ [36]. 


\begin{tabular}{|c|c|c|c|c|c|c|c|c|c|c|}
\hline & & $\begin{array}{l}\text { Num } \\
\text { micro }\end{array}$ & er of & & es $p$ & & & $\begin{array}{l}\text { Real-time } \\
\text { PCR }\end{array}$ & $\begin{array}{l}\text { Calculated } \\
\text { number of }\end{array}$ & $\begin{array}{l}\text { Estimated } \\
\text { number of }\end{array}$ \\
\hline & 1 & 2 & 3 & 4 & 5 & mean & & $\begin{array}{l}\text { (mean of } \\
\text { duplicates }\end{array}$ & $\begin{array}{c}\text { copies } \mu g^{-1} \\
\text { of DNA } \\
\end{array}$ & $\begin{array}{l}\text { copies per } \\
\text { oyster cell } \\
\end{array}$ \\
\hline 1 & 8 & 22 & 18 & 12 & 7 & 13.4 & + & 32.56 & $2.28 E+04$ & 5.30E-02 \\
\hline 2 & 32 & 33 & 48 & 57 & 22 & 38.4 & + & 28.27 & $3.62 E+05$ & 8.43E-01 \\
\hline 3 & 15 & 34 & 21 & 8 & 26 & 20.8 & + & 26.35 & $1.25 \mathrm{E}+06$ & $2.92 E+00$ \\
\hline 4 & 46 & 93 & 28 & 24 & 10 & 40.2 & + & 22.96 & $1.12 \mathrm{E}+07$ & $2.60 \mathrm{E}+01$ \\
\hline 5 & 13 & 11 & 21 & 29 & 34 & 21.6 & + & 24.22 & $4.95 E+06$ & $1.15 E+01$ \\
\hline 6 & 18 & 27 & 19 & 27 & 24 & 23 & + & 24.40 & $4.42 E+06$ & $1.03 E+01$ \\
\hline 7 & 23 & 37 & 34 & 23 & 24 & 28.2 & + & 25.48 & $2.20 E+06$ & $5.12 E+00$ \\
\hline 8 & 24 & 22 & 28 & 18 & 9 & 20.2 & + & 24.00 & $5.72 E+06$ & 1.33E+01 \\
\hline 9 & 8 & 12 & 18 & 9 & 15 & 12.4 & + & 23.43 & $8.25 E+06$ & $1.92 \mathrm{E}+01$ \\
\hline 10 & 8 & 12 & 6 & 11 & 15 & 10.4 & + & 24.99 & $3.06 \mathrm{E}+06$ & $7.13 \mathrm{E}+00$ \\
\hline 11 & 1 & 31 & 21 & 65 & 4 & 24.4 & + & 23.51 & $8.26 \mathrm{E}+06$ & $1.92 \mathrm{E}+01$ \\
\hline 12 & 5 & 17 & 16 & 16 & 8 & 12.4 & + & 25.25 & $2.58 \mathrm{E}+06$ & $6.00 E+00$ \\
\hline 13 & 12 & 18 & 23 & 9 & 26 & 17.6 & + & 23.96 & $6.17 \mathrm{E}+06$ & $1.44 \mathrm{E}+01$ \\
\hline 14 & 14 & 37 & 53 & 43 & 11 & 31.6 & + & 23.75 & 7.11E+06 & $1.65 E+01$ \\
\hline 15 & 32 & 32 & 12 & 12 & 24 & 22.4 & + & 24.50 & $4.31 E+06$ & $1.00 \mathrm{E}+01$ \\
\hline 16 & 23 & 30 & 50 & 65 & 53 & 44 & + & 24.24 & $4.50 \mathrm{E}+06$ & $1.05 E+01$ \\
\hline 17 & 43 & 20 & 33 & 40 & 15 & 30 & + & 22.7 & $1.31 \mathrm{E}+07$ & $3.05 E+01$ \\
\hline Mean & & & & & & 24.2 & & 24.97 & $5.15 \mathrm{E}+06$ & $1.20 \mathrm{E}+01$ \\
\hline
\end{tabular}

Table 4 - Comparison of results obtained by heart imprints (based on examination of 3 to 5 microscopic fields of view), conventional PCR and real-time PCR for flat oysters detected moderately infected by heart imprints. The estimated number of actin gene copies per oyster cell is deduced from the mean of DNA content of Ostrea edulis genome estimated at $2.33 \mathrm{pg}$ [36]. 


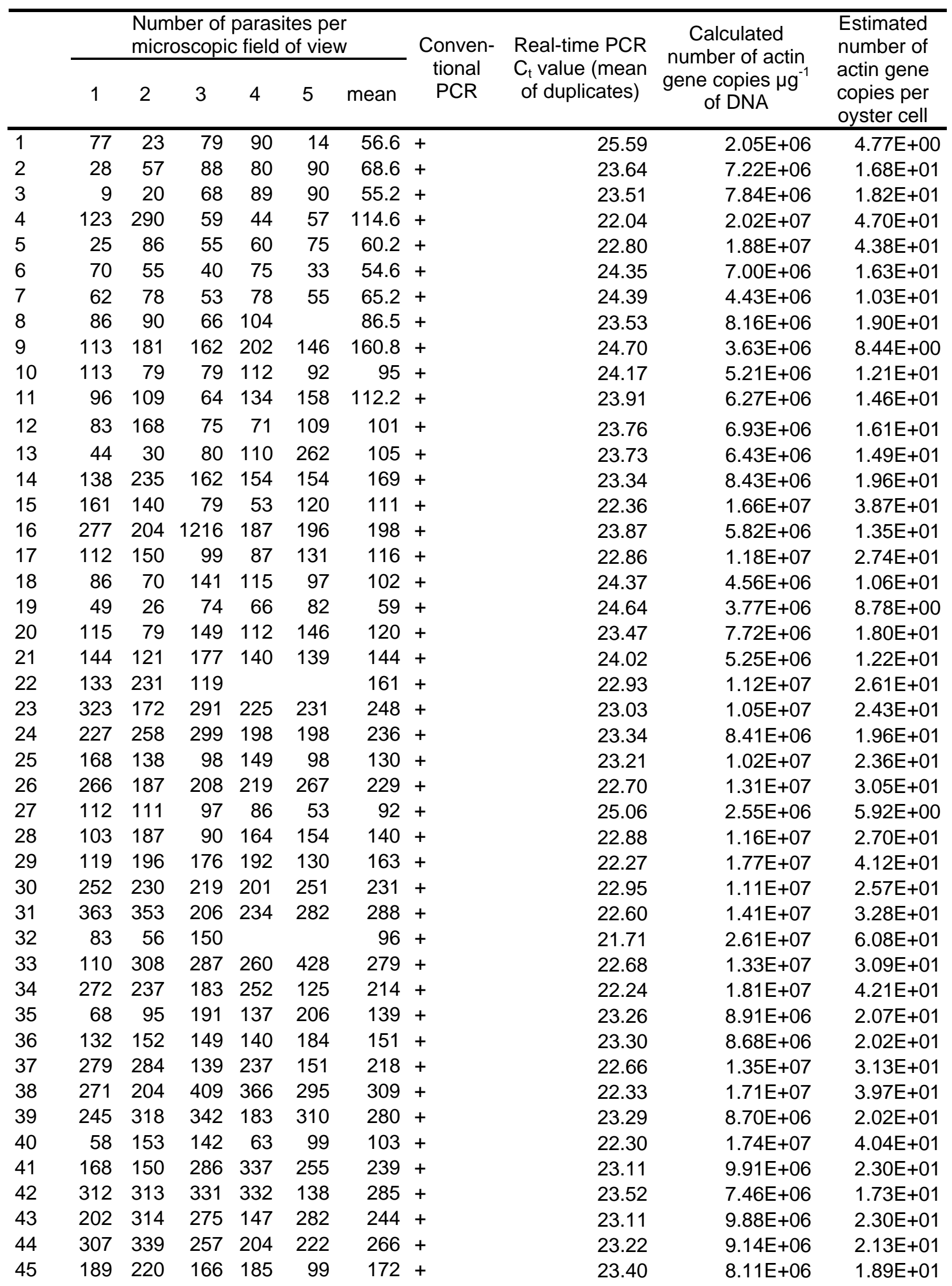




\begin{tabular}{rrrrrrrrrrr}
46 & 156 & 193 & 58 & 119 & 93 & $124+$ & 21.76 & $2.53 \mathrm{E}+07$ & $5.88 \mathrm{E}+01$ \\
47 & 95 & 137 & 140 & 220 & 82 & $135+$ & 24.91 & $2.83 \mathrm{E}+06$ & $6.58 \mathrm{E}+00$ \\
48 & 189 & 86 & 25 & 57 & 56 & $83+$ & 23.45 & $7.80 \mathrm{E}+06$ & $1.81 \mathrm{E}+01$ \\
\hline Mean & & & 154 & 23.34 & $1.02 \mathrm{E}+07$ & $2.38 \mathrm{E}+01$ \\
\hline
\end{tabular}

Table 5 - Comparison of results obtained by heart imprints (based on examination of 3 to 5 microscopic fields of view), conventional PCR and real-time PCR for flat oysters detected highly infected by heart imprints. The estimated number of actin gene copies per oyster cell is deduced from the mean of DNA content of Ostrea edulis genome estimated at $2.33 \mathrm{pg}$ [36]. 


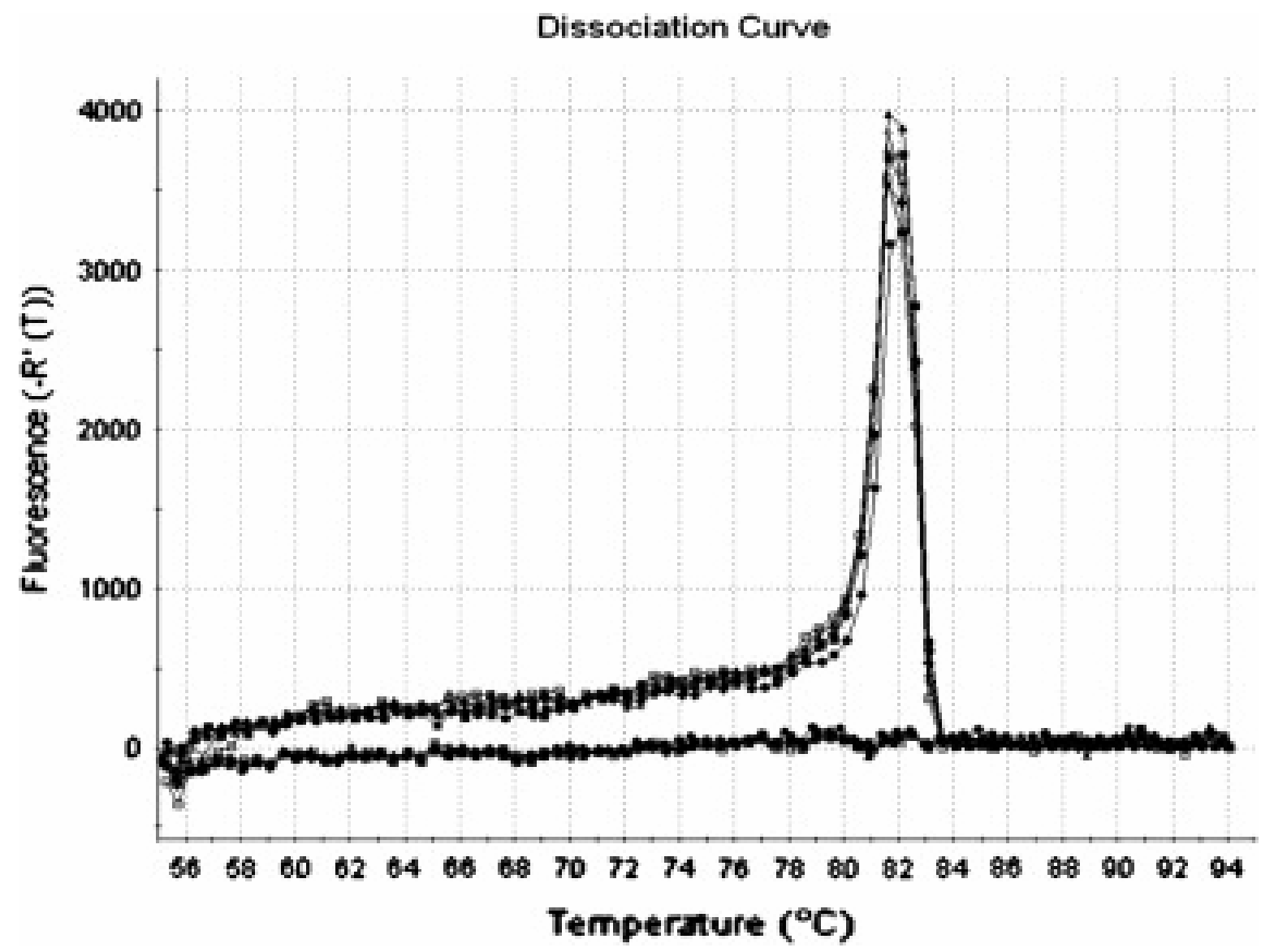

Fig. 1 - Melting curves of the amplified fragments generated by real-time PCR with DNA extracted from oysters confirmed to be infected by Bonamia ostreae (showing a melting peak between 81 and $82^{\circ} \mathrm{C}$ ) and with DNA extracted non infected flat oysters (baselines). 


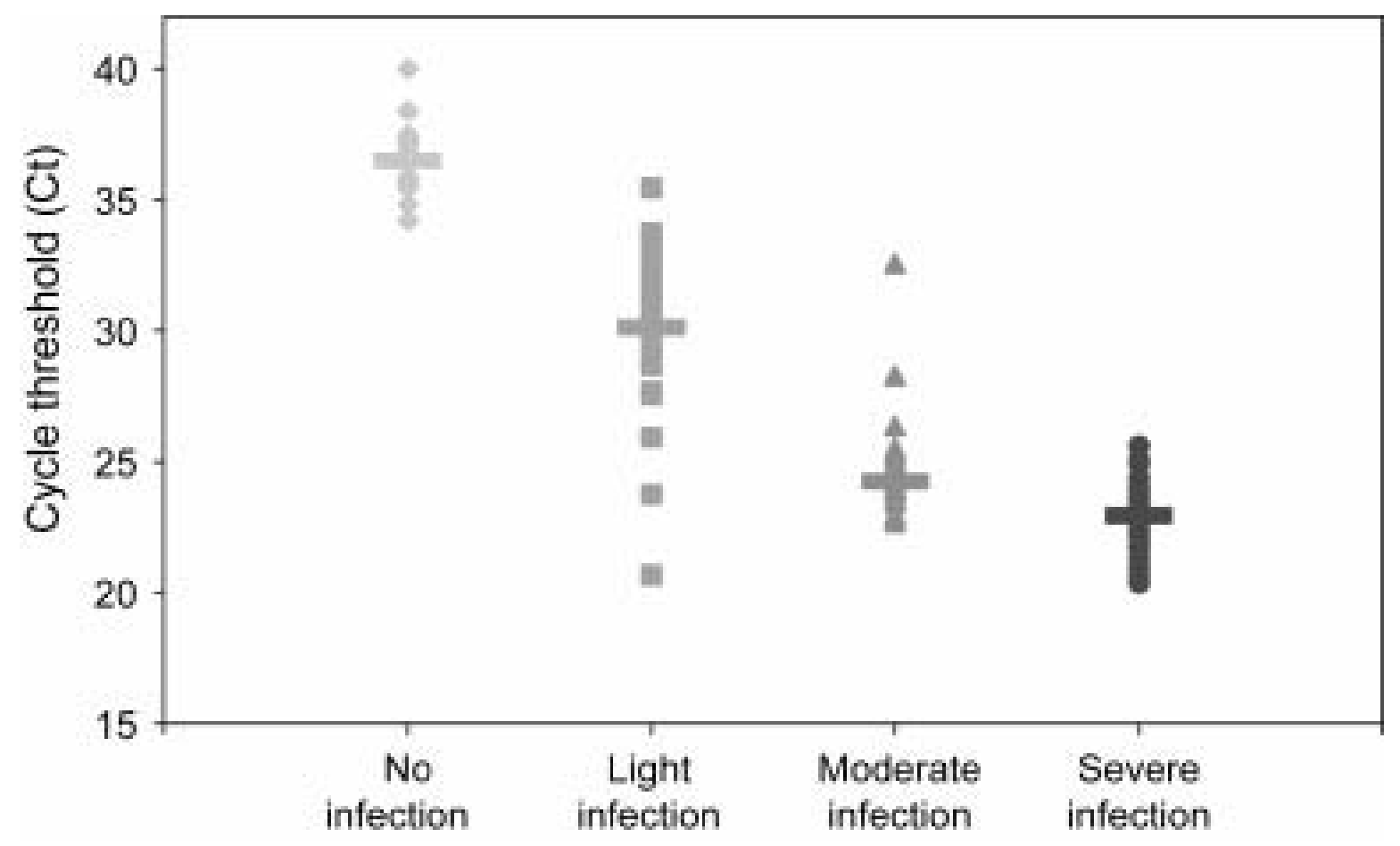

Fig. $2-C_{t}$ values obtained by the real-time PCR assay in flat oysters found not infected, lightly, moderately and highly infected by heart imprints. The values are means of duplicate amplifications. Bars indicate median value. 


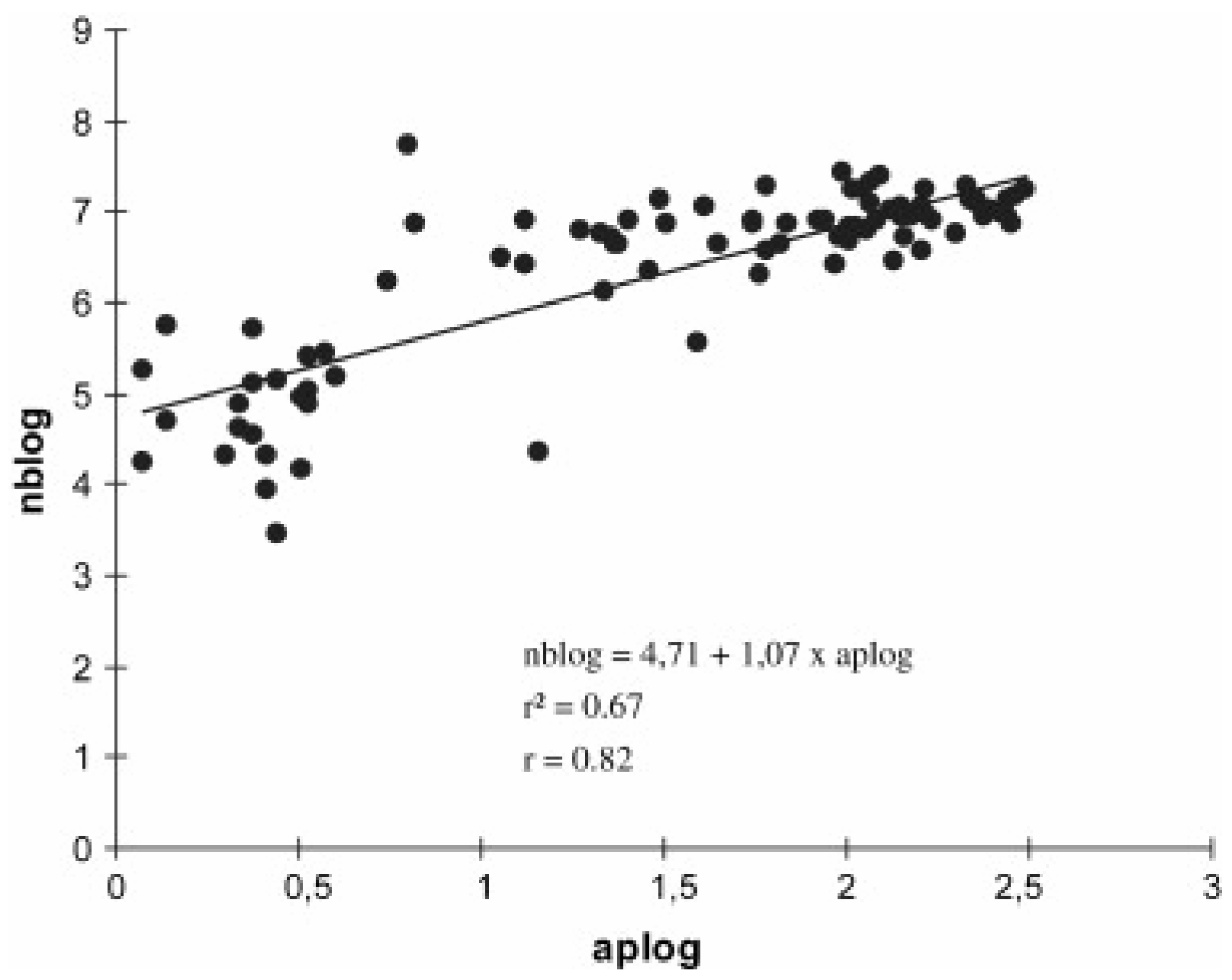

Fig. 3 - Linear regression obtained from log (1+ deduced number of Bonamia ostreae $\mu g^{-1}$ of total DNA $)=$ nblog and log $(1+$ number of parasites per microscopic field of view by examination of heart imprints) = aplog for 89 flat oysters tested in the present study (negative results for tissue imprints were excluded). 